\title{
BUD FERTILITY OF NEW TABLE GRAPE CULTIVARS AND BREEDING SELECTIONS IN THE SÃO FRANCISCO VALLEY ${ }^{1}$
}

\author{
PATRÍCIA COELHO DE SOUZA LEÃO ${ }^{2}$, EMILLE MAYARA DE CARVALHO SOUZA ${ }^{3}$, \\ JOSÉ HENRIQUE BERNARDINO NASCIMENTO³, JÉSSICA ISLANE DE SOUZA REGO ${ }^{3}$
}

\begin{abstract}
Knowledge of bud fertility is an important aid in selection of new cultivars of table grapes with high yield potential. The aim of this study was to determine the sprouting percentage and fertility index of buds of 11 cultivars and table grape breeding selections over five production cycles. The study was carried out at the Bebedouro Experimental Field of Embrapa Semiárido in Petrolina-PE, Brazil, in the period 20132015 considering 14 table grape genotypes and 5 production cycles as sources of variation. A randomized block experimental design was used, evaluating sprouting percentage and the mean bud fertility index. A significant effect of the genotype on sprouting was observed only in the first and second production cycles; however, bud fertility exhibited significant interaction between the genotype and the production cycle, and the highest mean values of bud fertility were obtained in the fifth cycle in the 2 nd semester of 2015 . The cultivars 'A Dona', 'A1105', 'BRS Clara', and Marroo Seedless' stood out through high bud fertility (mean values from 0.78 to 0.95 bunches/shoot) in all the cycles evaluated, with higher values in the terminal buds of the cane (8th and 9th buds). These results show the yield potential of these new cultivars in the São Francisco Valley region.
\end{abstract}

Index Terms: Vitis sp., tropical viticulture, seedless grape.

\section{BROTAÇÃO E FERTILIDADE DE GEMAS DE NOVAS CULTIVARES DE UVAS DE MESA E SELEÇÕES DE MELHORAMENTO NO VALE DO SÃO FRANCISCO}

\begin{abstract}
RESUMO - O conhecimento da fertilidade de gemas é um importante subsídio para a seleção de novas cultivares de uvas de mesa com alto potencial produtivo. O objetivo deste trabalho foi determinar a porcentagem de brotação e índice de fertilidade de gemas de 14 cultivares e seleções de melhoramento de uvas de mesa durante cinco ciclos de produção. O trabalho foi realizado no Campo Experimental de Bebedouro da Embrapa Semiárido, em Petrolina-PE, no período 2013-2015, considerando-se como fontes de variação 14 genótipos de uvas de mesa e 5 ciclos de produção. O delineamento experimental foi em blocos ao acaso, avaliando-se a porcentagem de brotação e o índice médio de fertilidade de gemas. Efeito significativo do genótipo sobre a brotação foi observada apenas no $1^{\circ}$ e $2^{\circ}$ ciclos de produção, entretanto a fertilidade de gemas apresentou interação significativa entre genótipo e ciclo de produção, sendo os maiores valores médios de fertilidade de gemas obtido no $5^{\circ}$ ciclo, no $2^{\circ}$ semestre de 2015 . As cultivares 'A Dona', 'A1105', 'BRS Clara' e Marroo Seedless' destacaram-se pela alta fertilidade de gemas (médias de 0,78 a 0,95 cachos.broto-1) em todos os ciclos avaliados, com valores mais elevados nas gemas apicais da vara $\left(8^{\mathrm{a}}\right.$ e $9^{\mathrm{a}}$ gemas). Estes resultados evidenciam o potencial produtivo dessas novas cultivares no Vale do São Francisco.
\end{abstract} Termos para indexação: Vitis sp., viticultura tropical, uva sem semente.

\footnotetext{
${ }^{1}$ (Paper 096-16). Received July 27, 2016. Accepted December 07, 2016.

${ }^{2}$ Researcher Embrapa Semiárido, BR 428, Km 152, Petrolina, PE, Zip Code 23, Petrolina-PE. Brasil. E-mail:patricia.leao@embrapa.br ${ }^{3}$ Biology Trainne Student, FFPP/UPE, Petrolina, PE, PIBIC/CNPq Embrapa Semiárido. E-mails: maiara_jua@hotmail.com; kynha_ jessica@hotmail.com; j.henrique.bernardino_12@hotmail.com
} 


\section{INTRODUCTION}

Vineyard yield depends on diverse production components, and bud fertility stands out as one of the most important.

The grapevine has two types of axillary buds: a lateral bud that gives rise to lateral shoots or "axillary shoots", and the compound or dormant bud. The differentiation of dormant buds into fruit-bearing buds occurs in three steps: formation of the undifferentiated primordium in the apical meristematic tissues of the buds, known as anlagen; differentiation of the anlagen into inflorescence primordia, tendrils, or shoots; and flower formation (MULLINS et al. 2000; BOTELHO et al. 2006). This process has its critical phase during the flowering period of the previous cycle (MULLINS, 2000; BOTELHO et al. 2006; JACKSON, 2008).

Environmental conditions have a great influence on bud fertility, and light intensity, temperatures, and water availability are the most important factors. High light intensity and temperatures promote synthesis of cytokinins that favor differentiation of the anlagen into inflorescence primordia (JACKSON, 2008).

Excess shoot vigor can lead to reduction of bud fertility in grapevines, which is correlated with the occurrence of bud necrosis (SHIKHAMANY, 1999). Thus, adoption of crop practices to control shoot vigor and increase the intensity of light on buds can increase bud fertility. Among these crop practices, control of irrigation and fertilization, especially nitrogen fertilization, the use of less vigorous rootstock, and application of growth regulators stand out.

According to Williams (2000), irrigation undertaken in the previous cycle can be considered the management practice of greatest importance on bud fertility of the 'Thompson Seedless' cultivar; excess of water can have more adverse effects than water deficit because it favors vegetative vigor and shading and has consequences in regard to necrosis and bud death.

Bud fertility has a strong genetic component, which results in wide variability of this trait among different cultivars. Knowledge of the position of fertile buds in each cultivar is an important aid for establishing more rational pruning techniques that result in an increase in vineyard yield (LEÃO; SILVA, 2003). The bud fertility of seven cultivars of table grapes in Italy showed that the cultivars 'Michele Paglieri', 'Italia', and 'Red Globe' had fertilities greater than 1.0 bunches/shoot as of the fifth bud of the cane, whereas 'Victoria' and 'Black Magic' were more fertile, with values above 2.0 bunches/ shoot, while the maximum fertilities observed in the cultivars 'Sublima' and 'Superior Seedless' were 0.7 bunches/shoot between the sixth and ninth buds of the cane (PIRAS et al. 2014). The seasonal climatic variations observed during the year in the São Francisco Valley determine high variability in bud fertility according to time of pruning. Five seedless grape cultivars evaluated in this region exhibited low bud fertility, ranging from 0.12 bunches/shoot in 'Superior seedless' to 0.37 bunches/shoot in 'Marroo Seedless', and there were higher values in the terminal buds among the ninth and tenth buds of the cane in all the cultivars (LEÃO; SILVA, 2003). In this same region, Ribeiro et al. (2008) observed a difference between the fertility of potential and real buds in the cv. 'Superior Seedless'; the mean of potential fertility was $33.5 \%$ and real fertility was $17.6 \%$, resulting in a mean rate of expression of fertility of $59.5 \%$.

These results show that bud fertility is a characteristic that determines vineyard yield and must be carefully considered for development and selection of new cultivars so as to obtain regular production at any time period of the year in this region.

Therefore, the aim of this study was to determine the sprouting percentage and fertility index of buds of 11 cultivars and breeding selections of table grapes, over five production cycles, as aids for recommendation of new cultivars and their inclusion in table grape breeding programs for the São Francisco Valley region.

\section{MATERIALS AND METHODS}

The experiment was carried out in the Bebedouro Experimental Field of Embrapa Semiárido in Petrolina, Pernambuco ( $9^{\circ} 09^{\prime} \mathrm{S}, 40^{\circ} 22^{\prime} \mathrm{W}$, and mean altitude of $365.5 \mathrm{~m}$ ) over five production cycles in the period of 2013 to 2015 .

Climate in the region is classified according to Koeppen as Bswh, which corresponds to hot semiarid. Daily and monthly data of mean air temperature and solar radiation were determined in an automated weather station in regard to the years 2013, 2014, and 2015 and are shown in Figures 1A and $1 \mathrm{~B}$.

The mean values of the mean, maximum, and minimum temperatures and solar radiation for the period from 15 to 45 days after pruning, which corresponds to the phase in which flower 
differentiation for the following cycle occurs, is shown in Table 1.

Plants were trained in a trellis system at a spacing of $3.0 \times 2.0 \mathrm{~m}$, grafted on the rootstock 'IAC 766', and drip irrigated. Pruning was carried out, leaving canes with approximately nine buds and the spurs, with three buds near the primary arm of the plant. Cropping practices and plant health treatments were those recommended for grapevine cultivation in the São Francisco Valley region (LEÃO; RODRIGUES, 2009).

A randomized block experimental design was used with four replications, and two plants were used per plot in a $5 \times 11$ factorial arrangement, represented by 11 genotypes of table grapes and five crop seasons or production cycles. The genotypes consisted of cultivars and breeding selections: BRS Clara, A Dona, CG 351, A1105, Marroo Seedless, selections from Embrapa Uva e Vinho (selection 8, selection 24, selection 36, selection 44), Thompson Seedless, and Crimson Seedless; the last two are commercial cultivars used in the region, which were considered as controls. The periods corresponding to the production cycles evaluated are shown in Table 1.

During the phenological phase of visible inflorescences, in shoots with approximately 5 leaves and $10 \mathrm{~cm}$ length or phase 12 according to Eichorn and Lorenz (COOMBE, 1995), the sprouting percentage and bud fertility index (no. of bunches/shoot) were evaluated by counting the number of buds, number of shoots, and number of bunches. Counting was performed for each bud position from the basal bud to the terminal bud of the cane. Sprouting percentage was obtained by the ratio between the number of sprouted buds and the total number of buds; and the real fertility index was obtained by dividing the total number of bunches by the total number of shoots.

The data were subjected to analysis of variance and the Tukey test at the 5\% level of probability for comparison of means.

\section{RESULTS AND DISCUSSION}

There was no influence of the production cycle on the sprouting of buds, obtaining mean values that ranged from $69.71 \%$ in the 2 nd semester of 2013 to $75.33 \%$ in the cycle of the 1 st semester of 2014 .

In contrast, effect of the genotype was observed on sprouting in the first and second production cycles, without significant differences being observed among the genotypes in the other cycles (Table 2). The mean values of sprouting percentage of 'CG 351' were greater than those of the selections 'CNPUV 8' and 'CNPUV 36' and of the cultivar 'A Dona'. Furthermore, the selection 'CNPUV 8' exhibited the lowest sprouting of buds,

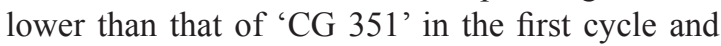
lower than all the other cultivars and selections in the second production cycle. In the other cycles, this selection maintained the tendency of bud sprouting lower than that of the other genotypes. These results are in agreement with those obtained by Lima (2013), who mentioned a sprouting rate ranging from 0.29 to 0.45 shoot.bud- ${ }^{-1}$ as a function of the rootstock used in the selection 'CNPUV 8'.

Bud fertility was influenced by the production cycle, that is, by the environmental conditions and management practices in each cycle, exhibiting mean values that ranged from 0.56 to 0.79 bunches/ shoot (Table 3). In Table 1, it can be observed that the first production cycle (2013.2) had higher mean, maximum, and minimum temperatures and solar radiation than the other cycles during the critical period of flower differentiation of the buds for the following cycle, which, according to Botelho et al. (2006), are conditions that induce the formation of the primordia of inflorescence. Nevertheless, in this study, a direct response of bud fertility to higher temperatures and solar radiation was not observed since these conditions did not favor an increase in fertility in the second production cycle (2014.1). The greatest mean value of bud fertility was obtained in the fifth production cycle (2015.2), greater than the mean values found in the second, third, and fourth production cycles. In the 2nd semester of 2013, bud fertility did not differ from the other production cycles. This result shows that other management and plant development factors are also at play in this physiological process. Management practices of irrigation (WILLIAMS, 2000; GUILPART et al. 2014), fertilizations, especially fertilization with nitrogen, which can induce an excess of vigor in branches (GUILPART et al. 2014), and growth regulators (BOTELHO et al. 2004a; 2004b) are among the main management factors that can act in differentiation of the primordia of inflorescence.

Bud fertility is a characteristic with strong genetic determination, which can be seen in Table 3 by the significant effect of genotype in all production cycles. The higher fertility index ( 0.78 to 0.95 bunches/shoot) were observed in 'A Dona', 'A1105', 'BRS Clara', and Marroo Seedless' genotypes, without significant differences observed among them. Intermediate bud fertility ( 0.54 to 0.74 bunches/shoot) were presented by the breeding selections of Embrapa Uva e Vinho: 'CNPUV 24', 
'CNPUV 44', 'CNPUV 36', and 'CNPUV 8'. On the other hand, genotypes 'CG351', 'Thompson Seedless', and 'Crimson Seedless' have showed low bud fertility ( 0.24 to 0.48 bunches/shoot). The commercial cultivars 'Thompson Seedless' and 'Crimson Seedless' exhibited the lowest bud fertility among all the genotypes evaluated. Low bud fertility in 'Thompson Seedless' has been indicated as one of the factors of the lack of success of this cultivar in the São Francisco Valley region. The fertility index of 0.33 bunches/shoot observed in this study in the cv. 'Thompson Seedless', in spite of representing low bud fertility, was higher than the indexes found by Leão and Silva (2003) and by Feldberg et al. (2008), respectively, in the São Francisco Valley region and the north of Minas Gerais State. In relation to the cultivar 'Crimson Seedless', the bud fertility index obtained in this study was similar to that observed for this cultivar in the north of Minas Gerais State (FELDBERG et al. 2008).

The genotypes that stood out through greater bud fertility maintained this tendency over the five production cycles, which is a positive characteristic because it indicates that these cultivars show a certain productive stability and are less subject to yield variations, the occurrence of which is common in tropical grape growing when two crops per year are produced. The breeding selections also exhibited high bud fertility and, in general, did not differ from the genotypes 'A Dona', 'A1105', 'BRS Clara', and Marroo Seedless'. 'CNPUV 44' selection with stable bud fertility of around 0.70 bunches/shoot over the five production cycles evaluated is noteworthy. However, greater change from one crop to another was observed in the other selections.

There was significant interaction between production cycles and genotypes only in the cultivar 'Crimson Seedless' and in the selection 'CNPUV 8', and, in the latter, the fifth production cycle (2015.2) favored the increase in bud fertility compared to the second and third production cycles while, in 'Crimson Seedless', greater bud fertility in that cycle was also observed, with significant differences for the 2013 and 2014 cycles (Table 3).

A comparison of the mean values of bud fertility by bud position, from the first to the ninth bud of the cane, is shown in Figure 2. The red grapes cultivars 'A Dona' and 'Marroo Seedless', which stood out among those with greatest bud fertility, were compared to the commercial cultivars 'Thompson Seedless' and 'Crimson Seedless' (Figure 2A). A increase was observed in the indexes of bud fertility of the cultivars 'A Dona' and 'Marroo Seedless' according to the position of the bud on the cane, reaching maximum values greater than 1.0 bunch/shoot at the eighth bud. A similar response was observed in genotypes of white grapes 'A1105' and 'BRS Clara', which achieved maximum fertility indexes with 1.16 and 1.21 bunches/shoot, respectively, in the terminal bud (ninth bud). These results indicate that the pruning recommendation for these cultivars should be a medium pruning, maintaining seven to eight buds on the cane.

In contrast, very low bud fertility indexes were observed in all the buds of the cane in the commercial cultivars 'Thompson Seedless', ranging from 0.22 (third bud) to 0.51 bunches/shoot (ninth bud), and 'Crimson Seedless', ranging from 0.17 (sixth bud) to 0.39 bunches/shoot (second bud).

This tendency of a increase in bud fertility according the more apical position of the bud on the cane was also observed in the cultivars 'Thompson Seedless' and 'Marroo Seedless' on five different pruning dates in the São Francisco Valley (LEÃO; SILVA, 2003). Piras et al. (2014), studying seven cultivars of table grapes, also observed an increase in bud fertility as of the middle part of the canes, with variations among the cultivars in the position of the buds with greatest fertility. These authors furthermore observed that in all the cultivars, a greater percentage of bud necrosis was found up to the third bud of the cane.

Identification of genotypes with high bud fertility allows selection of genotypes with high yield potential so that, it is also to consider the results regard the characteristics and quality of the bunches and berries, they can be recommended for commercial growing or otherwise be used in genetic breeding programs for development of new seedless grape cultivars for the tropical conditions of the São Francisco Valley, in the Northeastern region of Brazil 

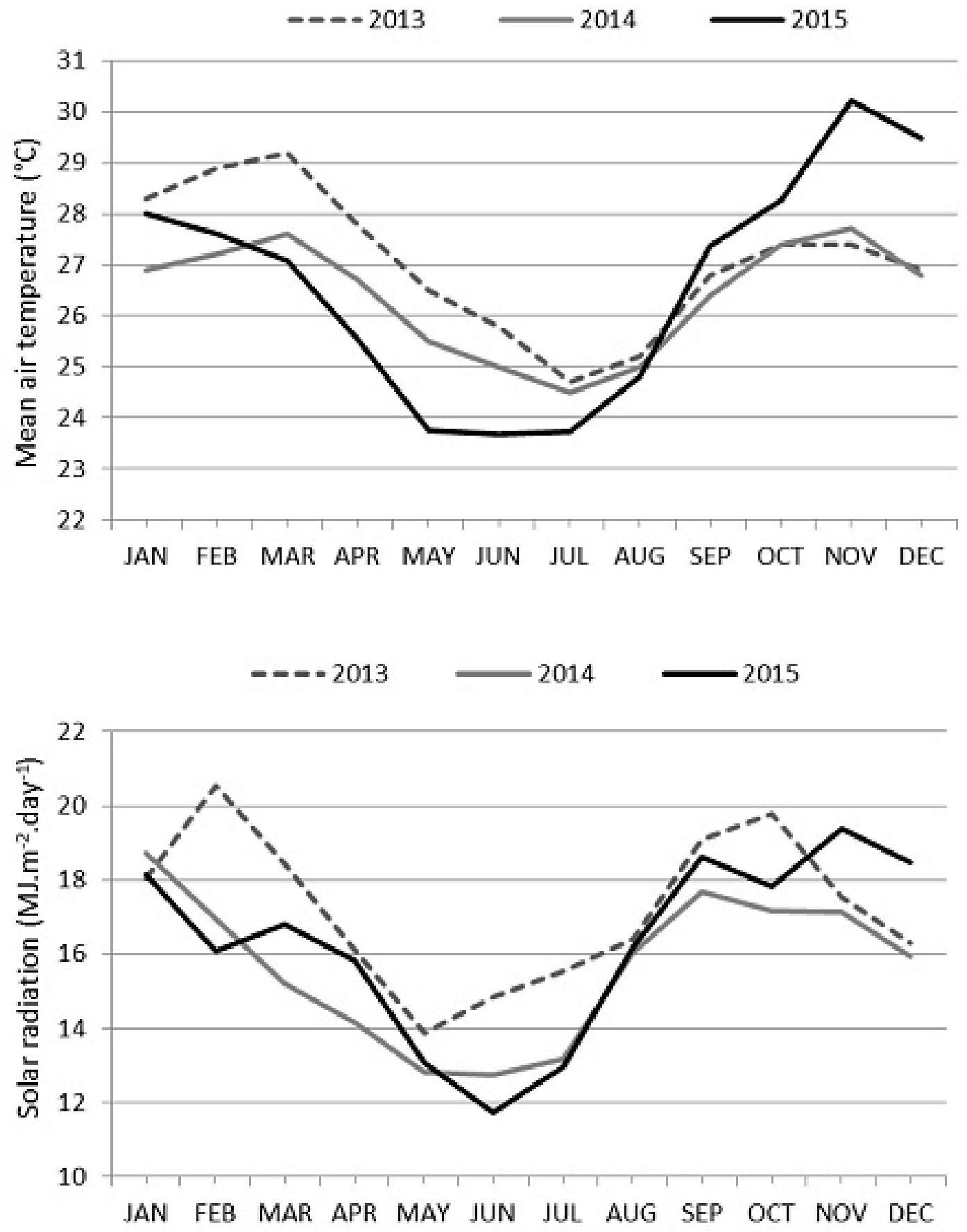

FIGURE 1- Monthly mean values of mean air temperature in ${ }^{\circ} \mathrm{C}(\mathrm{A})$ and Solar radiation in $\mathrm{MJ} . \mathrm{m}^{-2}$.day ${ }^{-1}$ (B) in the years 2013, 2014, and 2015, Bebedouro Experimental Field, Petrolina-PE, Brazil. 


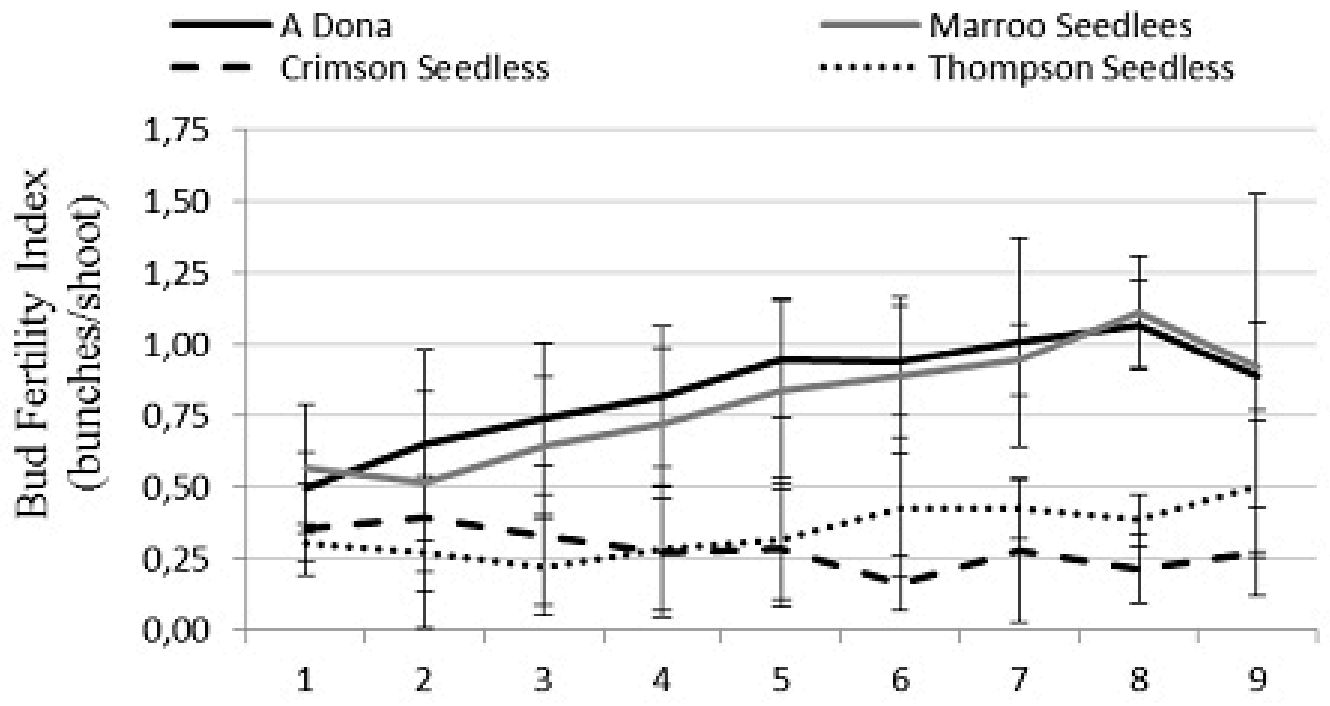

A
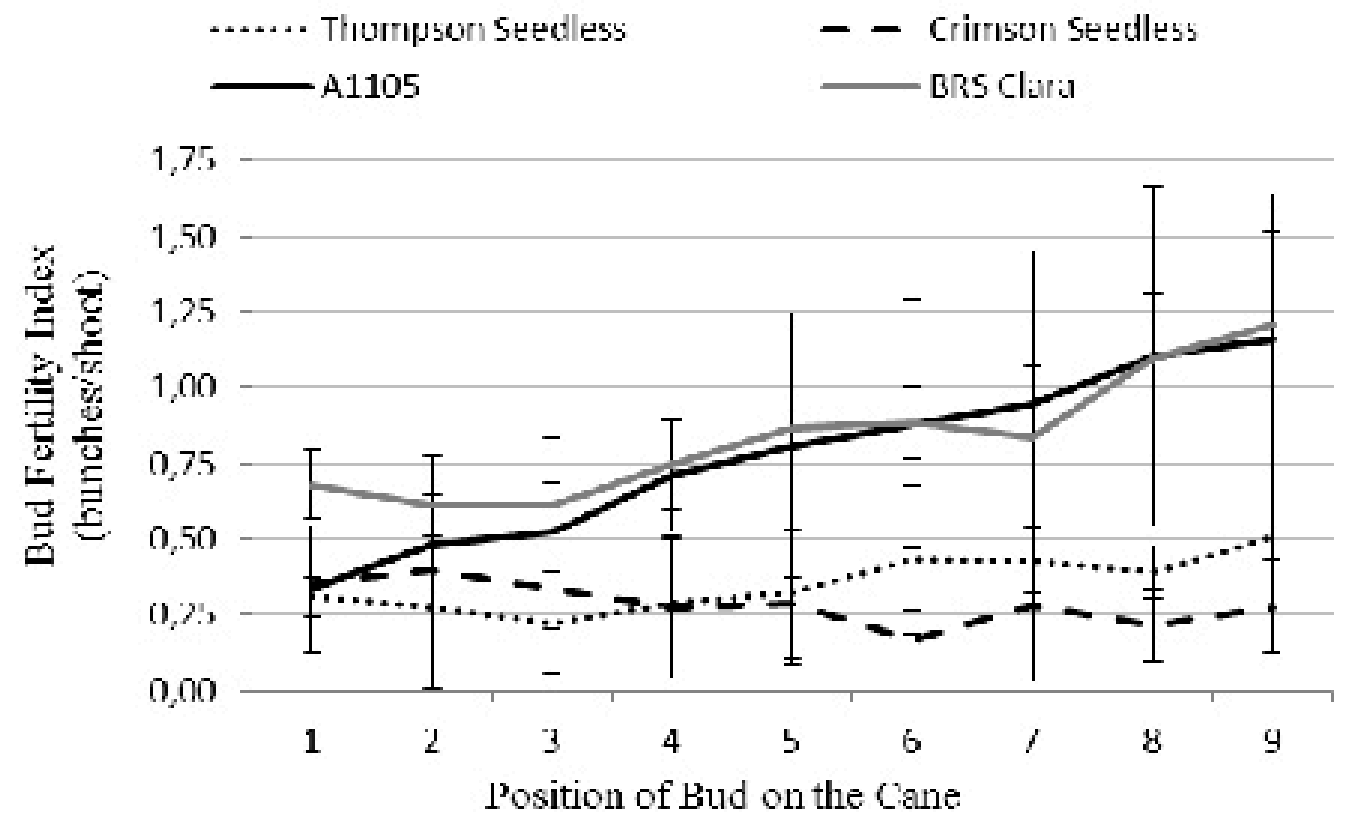

B

FIGURE 2- Mean values and standard deviation of fertility indexes by bud position on the cane of two red grape cultivars (A) and white grape cultivars (B) compared to the commercial 'Crimson Seedless' and 'Thompson Seedless'. 
TABLE 1- Pruning and harvest dates and mean values of mean, maximum, and minimum temperatures and solar radiation of five production cycles, 2013 to 2015.

\begin{tabular}{|c|c|c|c|c|c|c|}
\hline \multirow{2}{*}{$\begin{array}{l}\text { Production } \\
\text { cycle }\end{array}$} & \multirow{2}{*}{ Pruning date } & \multirow{2}{*}{ Harvest date $^{1}$} & MeanT $^{2}$ & $\operatorname{MaxT}^{2}$ & $\operatorname{MinT}^{2}$ & \multirow{2}{*}{$\begin{array}{c}\begin{array}{c}\text { Solar } \\
\text { Radiation }\end{array} \\
(\mathrm{MJ})\end{array}$} \\
\hline & & & & $\left({ }^{\circ} \mathrm{C}\right)$ & & \\
\hline 1st cycle & $15 / 10 / 13$ & $20 / 01-23 / 01 / 14$ & 27.76 & 34.39 & 21.57 & 18.29 \\
\hline 2nd cycle & $28 / 04 / 14$ & $30 / 07-22 / 08 / 14$ & 25.25 & 31.23 & 20.57 & 12.76 \\
\hline 3rd cycle & $22 / 10 / 14$ & $29 / 01-13 / 03 / 15$ & 27.29 & 33.41 & 22.95 & 16.32 \\
\hline 4th cycle & $30 / 03 / 15$ & $26 / 06-21 / 07 / 15$ & 24.28 & 30.00 & 19.91 & 14.08 \\
\hline 5th cycle & $26 / 08 / 15$ & $18 / 11-06 / 01 / 16$ & 27.82 & 34.80 & 21.68 & 17.91 \\
\hline
\end{tabular}

${ }^{1}$ The first and second dates refer to the date of the first and last cultivars/selections harvested, respectively. ${ }^{2}$ Mean values obtained for the period of 15 to 45 days after pruning, the critical phase for flower differentiation of the buds.

TABLE 2- Sprouting percentage of cultivars and/or breeding selections of table grapes over five production cycles, Petrolina-PE, Brazil, 2013-2015.

\begin{tabular}{lcccccc}
\hline \multicolumn{1}{c}{ Cultivar/ } & \multicolumn{5}{c}{ Production cycle } & Mean \\
\cline { 2 - 6 } \multicolumn{1}{c}{$\mathbf{2 0 1 3 . 2}$} & $\mathbf{2 0 1 4 . 1}$ & $\mathbf{2 0 1 4 . 2}$ & $\mathbf{2 0 1 5 . 1}$ & $\mathbf{2 0 1 5 . 2}$ & \\
\hline A 1105 & $68.64 \mathrm{ab}$ & $79.93 \mathrm{a}$ & $67.53^{\text {ns }}$ & $67.16^{\text {ns }}$ & $79.41^{\text {ns }}$ & $\mathbf{7 2 . 5 3} \mathbf{~ a b}$ \\
Marroo Seedless & $69.08 \mathrm{ab}$ & $85.40 \mathrm{a}$ & 62.79 & 75.71 & 84.47 & $\mathbf{7 5 . 4 9} \mathbf{~ a b}$ \\
A Dona & $63.11 \mathrm{ab}$ & $76.43 \mathrm{a}$ & 73.99 & 59.67 & 68.68 & $\mathbf{6 8 . 3 8} \mathbf{~ b c}$ \\
BRS Clara & $64.34 \mathrm{ab}$ & $79.13 \mathrm{a}$ & 73.75 & 77.89 & 81.66 & $\mathbf{7 5 . 3 6} \mathbf{~ a b}$ \\
Select. CNPUV 8 & $59.17 \mathrm{~b}$ & $41.26 \mathrm{~b}$ & 56.23 & 63.22 & 62.88 & $\mathbf{5 6 . 5 5} \mathbf{c}$ \\
Select. CNPUV 24 & $71.54 \mathrm{ab}$ & $73.30 \mathrm{a}$ & 78.13 & 80.24 & 55.85 & $\mathbf{7 1 . 8 1} \mathbf{~ a b}$ \\
Select. CNPUV 44 & $77.32 \mathrm{ab}$ & $77.92 \mathrm{a}$ & 62.56 & 71.41 & 76.22 & $\mathbf{7 3 . 0 9} \mathbf{~ a b}$ \\
Select. CNPUV 36 & $58.30 \mathrm{~b}$ & $75.35 \mathrm{a}$ & 69.97 & 79.30 & 67.28 & $\mathbf{7 0 . 0 4} \mathbf{b}$ \\
CG 351 & $84.77 \mathrm{a}$ & $86.69 \mathrm{a}$ & 78.97 & 82.17 & 77.68 & $\mathbf{8 2 . 0 6} \mathbf{a}$ \\
Thompson Seedless & $77.00 \mathrm{ab}$ & $71.63 \mathrm{a}$ & 87.89 & 68.86 & 78.45 & $\mathbf{7 6 . 7 7} \mathbf{~ a b}$ \\
Crimson Seedless & $73.58 \mathrm{ab}$ & $81.56 \mathrm{a}$ & 78.77 & 73.84 & 71.57 & $\mathbf{7 5 . 8 6} \mathbf{~ a b}$ \\
\hline Mean & $\mathbf{6 9 . 7 1 n s}$ & $\mathbf{7 5 . 3 3}$ & $\mathbf{7 1 . 8 7}$ & $\mathbf{7 2 . 6 8}$ & $\mathbf{7 3 . 1 0}$ & $\mathbf{7 2 . 5 4}$ \\
\hline CV (\%) & $\mathbf{1 2 . 6 6}$ & $\mathbf{1 5 . 0 5}$ & $\mathbf{1 9 . 3 2}$ & $\mathbf{1 4 . 0 6}$ & $\mathbf{1 7 . 5 5}$ & $\mathbf{1 5 . 9 4}$ \\
\hline
\end{tabular}

${ }^{1}$ Mean values followed by the same letter in the column do not differ among themselves by the Tukey test $(\mathrm{p}<0.05)$.; ns: not significant.

TABLE 3-Bud fertility index (bunches/shoot) of cultivars and/or breeding selections of table grapes over five production cycles, Petrolina-PE, Brazil, 2013-2015.

\begin{tabular}{|c|c|c|c|c|c|c|}
\hline \multirow{2}{*}{$\begin{array}{l}\text { Cultivar/ } \\
\text { Selection }\end{array}$} & \multicolumn{5}{|c|}{ Production cycle } & \multirow{2}{*}{ Mean } \\
\hline & 2013.2 & 2014.1 & 2014.2 & 2015.1 & 2015.2 & \\
\hline A 1105 & $1.00 \mathrm{ab}$ & $0.98 \mathrm{a}$ & $0.78 \mathrm{ab}$ & $0.83 \mathrm{a}$ & $1.06 \mathrm{ab}$ & $0.93 \mathrm{ab}$ \\
\hline Marroo Seedless & $0.74 \mathrm{abc}$ & $0.85 \mathrm{a}$ & $0.70 \mathrm{ab}$ & $0.59 \mathrm{ab}$ & $1.04 \mathrm{ab}$ & 0.78 abc \\
\hline A Dona & $1.15 \mathrm{a}$ & $0.83 \mathrm{a}$ & $0.90 \mathrm{a}$ & $0.67 \mathrm{ab}$ & $1.08 \mathrm{a}$ & 0.95 a \\
\hline BRS Clara & $0.79 \mathrm{ab}$ & $0.95 \mathrm{a}$ & $0.74 \mathrm{ab}$ & $0.87 \mathrm{a}$ & $0.86 \mathrm{abc}$ & 0.84 abc \\
\hline Select. CNPUV 8 & $0.67 \mathrm{abcAB}$ & $0.28 \mathrm{bcC}$ & $0.45 \mathrm{bcdBC}$ & $0.60 \mathrm{abAB}$ & $0.72 \mathrm{abcA}$ & 0.54 de \\
\hline Select. CNPUV 24 & $1.07 \mathrm{a}$ & $0.81 \mathrm{a}$ & $0.47 \mathrm{bcd}$ & $0.85 \mathrm{a}$ & $0.49 \mathrm{c}$ & 0.74 bcd \\
\hline Select. CNPUV 44 & $0.70 \mathrm{abc}$ & $0.68 \mathrm{ab}$ & $0.70 \mathrm{ab}$ & $0.75 \mathrm{a}$ & $0.79 \mathrm{abc}$ & $0.72 \mathrm{~cd}$ \\
\hline Select. CNPUV 36 & $0.74 \mathrm{abc}$ & $0.69 \mathrm{ab}$ & $0.57 \mathrm{abc}$ & $0.39 \mathrm{ab}$ & $0.85 \mathrm{abc}$ & 0.65 cde \\
\hline CG 351 & $0.51 \mathrm{bcd}$ & $0.32 \mathrm{bc}$ & $0.46 \mathrm{bcd}$ & $0.35 \mathrm{ab}$ & $0.75 \mathrm{abc}$ & 0.48 ef \\
\hline Thompson Seedless & $0.20 \mathrm{~cd}$ & $0.28 \mathrm{bc}$ & $0.25 \mathrm{~cd}$ & $0.39 \mathrm{ab}$ & $0.54 \mathrm{bc}$ & $0.33 \mathrm{fg}$ \\
\hline Crimson Seedless & $0.12 \mathrm{~dB}$ & $0.11 \mathrm{cB}$ & $0.20 \mathrm{~dB}$ & $0.25 \mathrm{bAB}$ & $0.54 \mathrm{bcA}$ & $0.24 \mathrm{~g}$ \\
\hline Mean & $0.70 \mathrm{AB}$ & $0.61 \mathrm{~B}$ & $0.56 \mathrm{~B}$ & $0.61 \mathrm{~B}$ & $0.79 \mathrm{~A}$ & 0.65 \\
\hline CV $(\%)$ & 31.72 & 28.34 & 24.18 & 37.83 & 27.55 & 30.39 \\
\hline
\end{tabular}

${ }^{1}$ Mean values followed by the same letter in the column do not differ among themselves by the Tukey test $(\mathrm{p}<0.05)$. 


\section{CONCLUSIONS}

- The genotype influenced the sprouting of buds in two production cycles, and the lowest sprouting was observed in the Embrapa Uva e Vinho selection 'CNPUV 8';

- Bud fertility was strongly determined by genetic and environmental factors, identifying genotypes of high, intermediate, and low fertility.

- The genotypes 'A Dona', 'A1105', 'BRS Clara', and 'Marroo Seedless' stood out with the highest mean indexes of bud fertility, and this bud fertility increased, reaching maximum values at the eighth and ninth buds of the cane.

\section{REFERENCES}

BOTELHO, R. V.; PIRES, E. J. P.; TERRA, M. $M$. Efeitos do cycocel na fertilidade de gemas e no crescimento dos ramos de videiras cv Itália (Vitis vinifera L.). Revista Brasileira de Fruticultura, Jaboticabal, v.26, n.1, p.78-81, 2004a.

BOTELHO, R.V.; PIRES, E.J.P.; TERRA, M.M. Fertilidade de gemas em videiras: fisiologia e fatores envolvidos. Ambiência, Guarapuava, v.2, n.1, p.129144, 2006.

BOTELHO, R.V.; PIRES, E.J.P.; TERRA, M.M.; MERCER, R.M.; KERNISKI, S. Efeitos do paclobutrazol na fertilidade de gemas e no crescimento dos ramos de videiras cv Rubi. Revista Brasileira de Fruticultura, Jaboticabal, v.26, n.2, p.345-347. 2004b.

COOMBE, B.G. Adoption of a system for identifying grapevine growth stages. Australian Journal Grape Wine Research, Glen Osmond, v.1, p.100-110, 1995.

FELDBERG, N.P.; DIAS, M.S.C.; REGINA, M. de A. Avaliação agronômica de cultivares de videiras apirenas na região de Jaíba, Minas Gerais. Revista Brasileira de Fruticultura, Jaboticabal, v.30, n.3, p.644-648, 2008.

GUILPART, N., METAY, A.; GARY, C. Grapevine bud fertility and number of berries per bunch are determined by water and nitrogen stress around flowering in the previous year. European Journal of Agronomy, Amsterdam, v.54, p.9-20, 2014.
JACKSON, R. S. Grapevine structure and function In: JACKSON, R.S. (Ed.). Wine science principles and applications. $3^{\text {rd }}$ ed. San Diego: Academic Press, 2008. p.50-107.

LEÃO, P.C. de S.; RODRIGUES, B.L. Manejo da copa. In: SOARES, J.M.; LEÃO, P.C. de S. (Org.). A Vitivinicultura no semiárido brasileiro. Brasília, DF: Embrapa Informação Tecnológica, 2009. p.295347.

LEÃO, P.C. de S.; SILVA, E.E.G. da. Brotação e fertilidade de gemas em uvas sem sementes no Vale do São Francisco. Revista Brasileira de Fruticultura, Jaboticabal, v.25, n.3, p.375-378, 2003.

LIMA, F. B. F. Avaliações agronômicas de uma seleção de videira apirência ('seleção 8') da Embrapa Uva e Vinho sobre diferentes portaenxertos. 2013. 57 f. Dissertação (Mestrado em Produção Vegetal) - Universidade do Estado da Bahia (PPHI/DTCS/UNEB), Juazeiro, 2013.

MULLINS, M.G.; BOUQUET, A.; WILLIAMS, L.E. Biology of the grapevine. Cambridge: University Press, 2000. 239 p

PIRAS, F.; LOVICU, G.; ZURRU, R. Observations on Some Agronomic Traits of Cultivars of Table Grapes. Acta Horticulturae, The Hague, n.1032, p.243-351, 2014.

RIBEIRO, V.G.; VILARONGA, C.P.P.; SIQUEIRA, P.X.; ASSIS, J.S. de; QUEIRÓZ, S.O.P.; LOPES, S.J. Expressão da fertilidade de Gemas da 'Superior Seedless' no município de Petrolina (PE). Revista Caatinga, Mossoró, v.21 n.3, p.231-235, 2008.

SHIKHAMANY, S.D. Physiology and cultural practices to produce seedless grapes in tropical environments. In: CONGRESSO BRASILEIRO DE VITICULTURA E ENOLOGIA, 9., 1999, Bento Gonçalves. Anais... Bento Gonçalves: EmbrapaCNPUV, 1999. p.43-48.

WILLIAMS, L.E. Bud development and fruitfulness of grapevines. In: CHRISTENSEN, L.P. (Ed.). Raisin Production manual. Oakland: University of California, 2000. p.24-29. 